\title{
Monte Carlo Simulation in a Peruvian Highway
}

\author{
Jean Carlos Espinoza Jaco*, Claudia Margarita Lopez Galarza, Roy Monteagudo Venero, \\ Jimmy Alberth Deza Quispe
}

Faculty of Engineering, Universidad Continental, 12001 Huancayo, Perú

Received June 22, 2021; Revised July 26, 2021; Accepted August 27, 2021

\begin{abstract}
Cite This Paper in the following Citation Styles
(a): [1] Jean Carlos Espinoza Jaco, Claudia Margarita Lopez Galarza, Roy Monteagudo Venero, Jimmy Alberth Deza Quispe , "Monte Carlo Simulation in a Peruvian Highway," Civil Engineering and Architecture, Vol. 9, No. 6, pp. 1727-1734, 2021. DOI: 10.13189/cea.2021.090606.
\end{abstract}

(b): Jean Carlos Espinoza Jaco, Claudia Margarita Lopez Galarza, Roy Monteagudo Venero, Jimmy Alberth Deza Quispe (2021). Monte Carlo Simulation in a Peruvian Highway. Civil Engineering and Architecture, 9(6), 1727-1734. DOI: $10.13189 /$ cea.2021.090606.

Copyright $\bigcirc 2021$ by authors, all rights reserved. Authors agree that this article remains permanently open access under the terms of the Creative Commons Attribution License 4.0 International License

\begin{abstract}
Highways and roads are important for nations' development and life quality. This is not different for Peru. A highway project called Daniel Alcides Carrión is expected to provide a solution to the over-employed Carretera Central road. This is a multimillionaire and important infrastructure project. Hence, it is important to evaluate the possible sustainability risks. In consequence, this study employed the Monte Carlo simulation for such a purpose. First, variables have been chosen and segregated into input and output. Variables like the initial investment, recurrent maintenance, periodical maintenance, savings in the operative cost of vehicles, and time savings employed the triangular distribution. Traffic growth and inflation rate employed the Pert distribution. The project's Net Present Value and Internal Rate of Return have been selected as output variables. Crystal Ball software has been employed to perform the Monte Carlo analysis. Consequently, this research found a high probability that the highway can become a profitable project due to its Net Present Value and Internal Rate of Return. Moreover, savings in operative costs of vehicles and traffic growth rate had positive impacts on the project's Net Present Value. However, the initial investment had a negative relationship with the output variable. Hence, the new highway should take prevision policies to maintain traffic flux. Thus, avoid closures that can have both human and natural sources. This study is the first in the Peruvian academic literature regarding highways risk analysis. Moreover, this study provides researchers, state officials, future highway managers, and users' valuable information to elaborate preventive measures to maintain the highway's social sustainability
\end{abstract}

and increase its benefits.

Keywords Monte Carlo Simulation, Risk Analysis, Sensitivity Analysis, Highway, Project NPV

\section{Introduction}

Road infrastructure is highly important for a country's economic development. Also, a country with an excellent road network is highly competitive [1]. Therefore, road networks improve commerce, jobs, business, and life quality [2]. The developed countries have a complex road system that enhances connectivity in their territories [3], while other countries have poor road networks that difficult their economic development [4].

Among those countries, Latin American nations have gaps among their current infrastructure demand and their infrastructure offer [5]; for instance, Peru has a gap estimated at 31 billion dollars [6]. This alternative contemplates a road of 136 kilometers and 14.40 meters width. It is called "Nueva Carretera Central" or "Daniel Alcides Carrión" highway. This project is going to be the core of this research.

Although a country can improve its public infrastructure investment, it does not mean that public resources are wasted without technical criteria. In effect, many public works do not meet the public needs. Reference [9] states that overestimated public works are unsolvable in the future. Hence, it wastes scarce efforts and resources. Thus, wasting resources creates 
inefficiency in public resource management [10].

There are tools with the capability to predict risky project profitability scenarios. The risk analysis identifies the potential risks before and after the project realization. It explores variations in the Net Present Value or NPV and their probability of occurrence [11]. Moreover, sensitivity analysis examines elements that might change the project sustainability in different scenarios [12].

The Peruvian national guidelines obligate public projects to have both risk and sensitivity analyses. They are important to identify scenarios where the project profitability is endangered. Those undesirable scenarios may come from natural or human resources [13]. In consequence, when risks are identified, actions are taken to prevent or mitigate them. Monte Carlo simulation is a way to explore those scenarios. It examines the project NPV variation through random changes in the input variables and their probability of occurrence [14].

Therefore, the Monte Carlo simulation shows the input variables' variation across time and their impact on the output variable. In consequence, this research will perform the Nueva Carretera Central risk analysis employing the Monte Carlo simulation.

\section{Literature Review}

\subsection{Previous Studies}

The Monte Carlo analysis has been employed to estimate the risks of public investment projects; however, this tool still is not widely employed in Peru. One of the few Monte Carlos studies has been performed in an education project [15]. In that study, the input variables were: initial investment, operation and maintenance, and social benefits; while, the outputs were project NPV and project Internal Rate of Return or IRR. That research found that the probability of the project NPV being bigger than zero was $67.10 \%$. Moreover, the analysis showed the importance of students' family incomes and attendance.

Internationally, the Monte Carlo analysis has been employed in road building and transport management. For instance, one study applied the Monte Carlo simulation in a set of road maintenance projects that found that costs were crucial to keeping the project sustainable [16].

Moreover, another research employed Monte Carlo simulation to study the effectiveness of railway construction projects. That research found that the benefits have been correlated to investment and tax deductions [17]. Moreover, [18] stated that railway operators have had to minimize maintenance and rehabilitation costs, but and at the same time increase service reliability.

They build three scenarios employing construction, maintenance, and operational restrictions as inputs and user benefits as the only output. Hence, they found that some maintenance techniques have had higher user value than others [18]. Also, another study employed a portfolio of railway construction projects to estimate their risk by Monte Carlo simulation. They encountered that equipment availability and placement issues have been the riskiest factors in all the project stages [19].

Furthermore, the Monte Carlo simulation has been employed in investment projects focused on the risk of exceeding the initial budget. Thus, their inputs were tradable goods, non-tradable goods, skilled labor, unskilled labor, land acquisition, and transfer payments. That study found that the risk of surpassing the initial budget was $32.74 \%$. Also, it recommended analyzing both economic and financial risks to establish different strategies to manage the risks [20].

Similarly, an investigation employed Monte Carlo analysis for construction project management. The risks have been classified in technical, construction, physical, organization, financial, management, political, logistics, and design. The results showed that the most feared risk was the government change. On the other hand, the least feared risk was labor availability. That study concluded that Monte Carlo simulation was a necessary tool for risk management [21].

Finally, [22] analyzed the transport infrastructure project risks using Monte Carlo analysis and the Danish technical guides. Input variables were construction costs, travel time savings, maintenance costs, and accident unit price. The only output variable was the project NPV. The simulation showed that the most relevant variables were traveling time savings and maintenance costs. However, time travel had a positive relationship with the output variable; while, the second had a negative relationship with the output [22]. A brief resume char is portrayed in Table 1.

\subsection{Theoretical Basis}

\subsubsection{Risk Analysis}

Reference [23] states that the risk analysis' objective is to identify the effects of the simulated changes on the output variable. Moreover, [24] claims that this analysis should anticipate the possible future changes that can affect the project's sustainability.

The risk analysis determines the sensitivity of the outputs towards the uncertainty of the inputs [25]. Also, it can measure the input intensity on the output [25]. Understanding uncertainty is necessary because it is not feasible to predict something with $100 \%$ certainty. Therefore, the results are only probabilistic, then it might really happen or not [24]. Risk simulations can establish the variables' power to cause a disruption.

Both [24] and [25] suggest identifying conservative, optimistic, and pessimistic scenarios. The first is based on the expected results, the second is based on results that overpass the initial expected results, and the last describes a scenario where the odds are against the project. In sum, 
those scenarios should provide a better understanding of the project and its possible variations in the future.

\subsubsection{Monte Carlo}

The name of the Monte Carlo simulation is based on randomness and repetition that give distribution probabilities [25]. In this analysis, a rank of probable results is provided [24]. Therefore, it can determine the project risks [26]. This simulation produces random numbers that can estimate probabilistically different scenarios. Hence, it builds the distribution probability with the potential to meet a real scenario. This scenario is only reached when the model becomes stable [15].

Furthermore, [15] states that it is possible to get a probabilistic distribution of the output by the input, thus, enabling the researcher to meet the probabilistic output value, standard deviation, and upper and lower limits.

Consequently, [25] and [24] recommend using the Monte Carlo simulation to evaluate the variation of the objective variable to assess risk management. Hence, we believe that this method provides an appropriate evaluation for its random numbers and situations. Otherwise, the risk analysis may be subject to an author's own point of view that could distort it.

\section{Methods}

To analyze the risk of the Daniel Alcides Carrión project, it was necessary to rebuild its cash flow. Hence, Peruvian road guidelines [27] and the social conversion factors [13] have been followed. The Crystal Ball software has been employed for the entire process.

The initial investment, recurrent maintenance, periodical maintenance, savings in operative vehicle costs, savings in time costs, inflation, and traffic growth rate were chosen as inputs variables. Inflation and traffic growth rate used the Pert distribution, while the other variables employed the triangular distribution.

The project's NPV and IRR were selected as outputs, and 5000 iterations were harnessed to obtain the results. Figure 1 shows the flow chart of the entire process.

Table 1. Previous studies

\begin{tabular}{|c|c|c|}
\hline Author & Title & Results \\
\hline 15 & $\begin{array}{l}\text { Análisis de riesgo mediante el método de } \\
\text { simulación de Montecarlo aplicado a la inversión } \\
\text { pública en el sector educativo peruano: el caso } \\
\text { del departamento de Puno. }\end{array}$ & $\begin{array}{l}\text { In a school project in the Peruvian Andes, the probability of NPV being } \\
\text { bigger than zero was } 67.10 \% \text {. To keep the project sustainable, the students' } \\
\text { income and attendance were key factors. }\end{array}$ \\
\hline 16 & $\begin{array}{l}\text { A Monte Carlo simulation method for risk } \\
\text { management in road pavement maintenance } \\
\text { projects }\end{array}$ & $\begin{array}{l}\text { In a road maintenance project, an important factor for sustainability was } \\
\text { operation and maintenance costs. }\end{array}$ \\
\hline 17 & $\begin{array}{l}\text { The transport construction investment project } \\
\text { effectiveness assessment by Monte Carlo } \\
\text { Method }\end{array}$ & $\begin{array}{l}\text { In a railway project, tax deduction and profits were necessary for its } \\
\text { sustainability. }\end{array}$ \\
\hline 18 & $\begin{array}{l}\text { Lifecycle Based User Value Analysis of Rail - } \\
\text { Road Level Crossings: Probabilistic Approach } \\
\text { Using Monte Carlo Simulation }\end{array}$ & $\begin{array}{l}\text { In a railway project, factors as construction, maintenance, and operational } \\
\text { restrictions were harnessed as inputs, while user benefits were employed as } \\
\text { output. The combination of maintenance strategies had different impacts on } \\
\text { the project's sustainability. }\end{array}$ \\
\hline 19 & $\begin{array}{l}\text { Using Monte Carlo simulation to create a ranked } \\
\text { check list of risks in a portfolio of railway } \\
\text { construction projects }\end{array}$ & $\begin{array}{l}\text { A set of railway projects found that equipment availability and placement } \\
\text { had a huge impact on the investment and maintenance stages. }\end{array}$ \\
\hline 20 & $\begin{array}{l}\text { Monte Carlo Method in Risk Analysis for } \\
\text { Investment Projects }\end{array}$ & $\begin{array}{l}\text { In a set of investment projects, the risk of surpassing the initial budget was } \\
32.74 \% \text { because of labor costs. }\end{array}$ \\
\hline 21 & $\begin{array}{l}\text { Monte Carlo Simulation Applications for } \\
\text { construction }\end{array}$ & In a construction project, the riskiest factor was the political change. \\
\hline 22 & $\begin{array}{l}\text { Assessment of transport infrastructure projects } \\
\text { using Monte Carlo simulation: The CBA-DK } \\
\text { model }\end{array}$ & $\begin{array}{l}\text { In a transport project, the most important factors for keeping the } \\
\text { sustainability of the project were time savings and maintenance costs. }\end{array}$ \\
\hline
\end{tabular}




\section{Results}

Figure 2 shows the scenarios that considered the project's NPV as the output variable. Moreover, it shows a certainty of $99.46 \%$ that the project's NPV will be bigger than 3292 and lower than 5443 million dollars. Descriptive statistics are presented in Table 2. Table 3 depicts the project's NPV probability of occurrence. Hence, the project's NPV will be between 4000 and 4500 million dollars. Moreover, there is a low probability that the project's NPV will be less than 3299 million dollars.

Figure 3 portrays the sensitivity analysis. It shows that operative vehicle costs and traffic growth rate had positive effects on the output. Then, as long as the highway saves costs for drivers, it is going to be profitable. Moreover, the highway needs to attract more vehicles to be sustainable. Nonetheless, the riskiest variable was the initial investment.

Table 2. Descriptive statistics

\begin{tabular}{|c|c|}
\hline Statistic & Values \\
\hline Iteration & 5000 \\
\hline Base Case $^{*}$ & 4,435 \\
\hline Mean* & 4,365 \\
\hline Median* & 4,360 \\
\hline Standard Deviation* & 384,958 \\
\hline Variance* & 148,192 \\
\hline Bias & 0.0598 \\
\hline Kurtosis & 2.95 \\
\hline Coefficient of variation & 0.0882 \\
\hline Min* & 3,089 \\
\hline Max* & 5,820 \\
\hline Mean standard error* & 5.444 \\
\hline
\end{tabular}

Table 3. Distribution of the project's NPV odds

\begin{tabular}{|c|c|}
\hline Rank* & Probability \\
\hline$<3,299$ & $0.25 \%$ \\
\hline $3,299-3,500$ & $0.81 \%$ \\
\hline $3,500-4,000$ & $15.97 \%$ \\
\hline $4,000-4,500$ & $46,60 \%$ \\
\hline $4,500-5,000$ & $31.18 \%$ \\
\hline $5,000-5,449$ & $5.19 \%$ \\
\hline
\end{tabular}

Table 4. Distribution of the project's IRR odds

\begin{tabular}{|c|c|}
\hline Rank & Probability \\
\hline$<18 \%$ & $0.04 \%$ \\
\hline $18 \%-19 \%$ & $3.43 \%$ \\
\hline $19 \%-20 \%$ & $10.27 \%$ \\
\hline $20 \%-21 \%$ & $14.69 \%$ \\
\hline $21 \%-22 \%$ & $20.95 \%$ \\
\hline $22 \%-23 \%$ & $23.31 \%$ \\
\hline $23 \%-24 \%$ & $18.53 \%$ \\
\hline $24 \%-25 \%$ & $7.43 \%$ \\
\hline
\end{tabular}

$*$ in millions of US\$ dollars

This budget was going to be about 3000 million dollars but can grow because of additional work. Highway geography can play a significant role here because it pretends to cross the Andes mountain range. Moreover, the project execution might suffer delays because of political instability and natural phenomena. Figure 4 depicts the Monte Carlo when the project's IRR is chosen. It shows an existing probability of $99.96 \%$ that the project's IRR will be between $18 \%$ and $26 \%$. Finally, Table 4 depicts a low probability that the project's IRR can be less than $18 \%$ or more than $26 \%$, and a high probability that project's IRR can be placed between $21 \%$ and $23 \%$. 


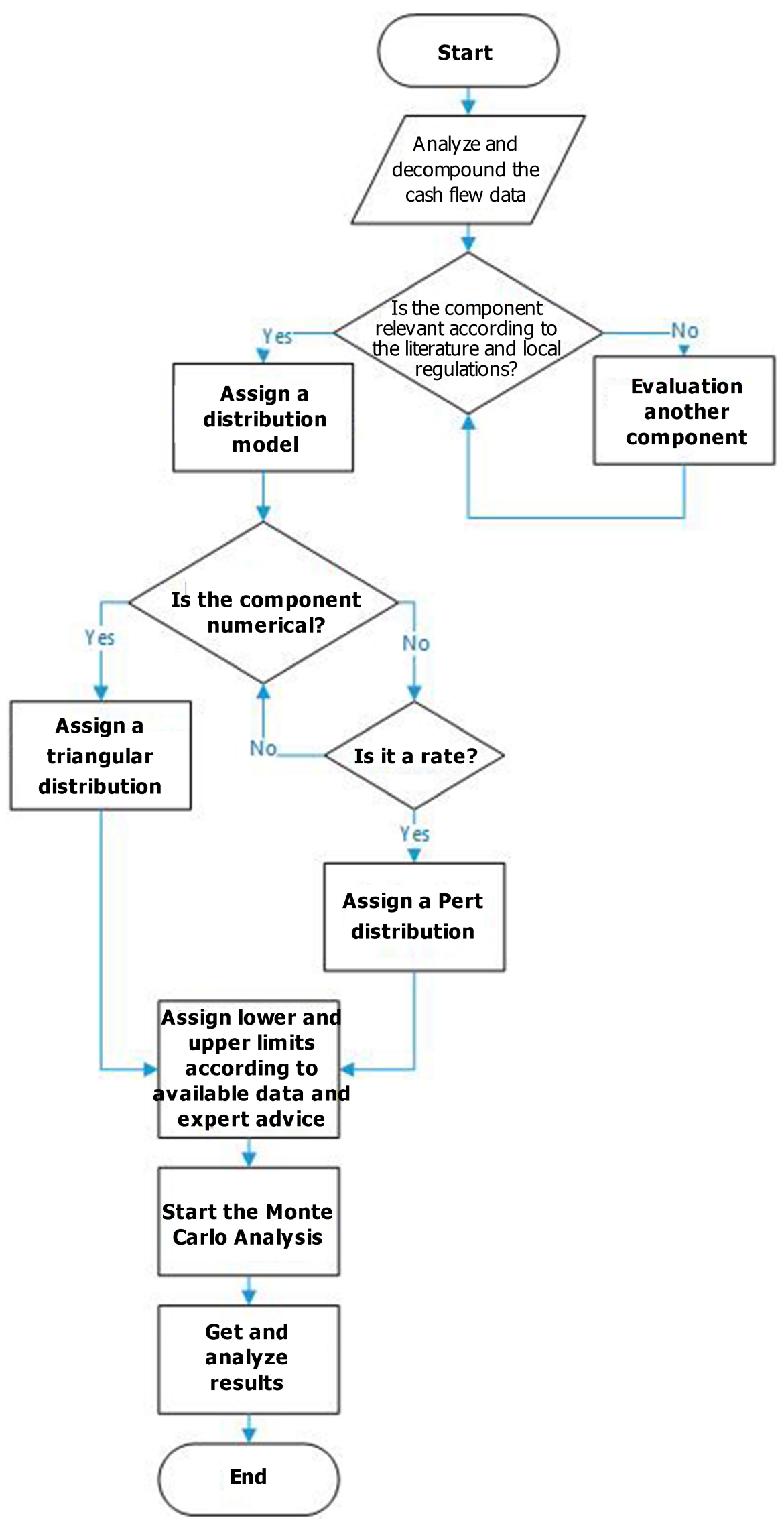

Figure 1. Monte Carlo simulation flow chart 


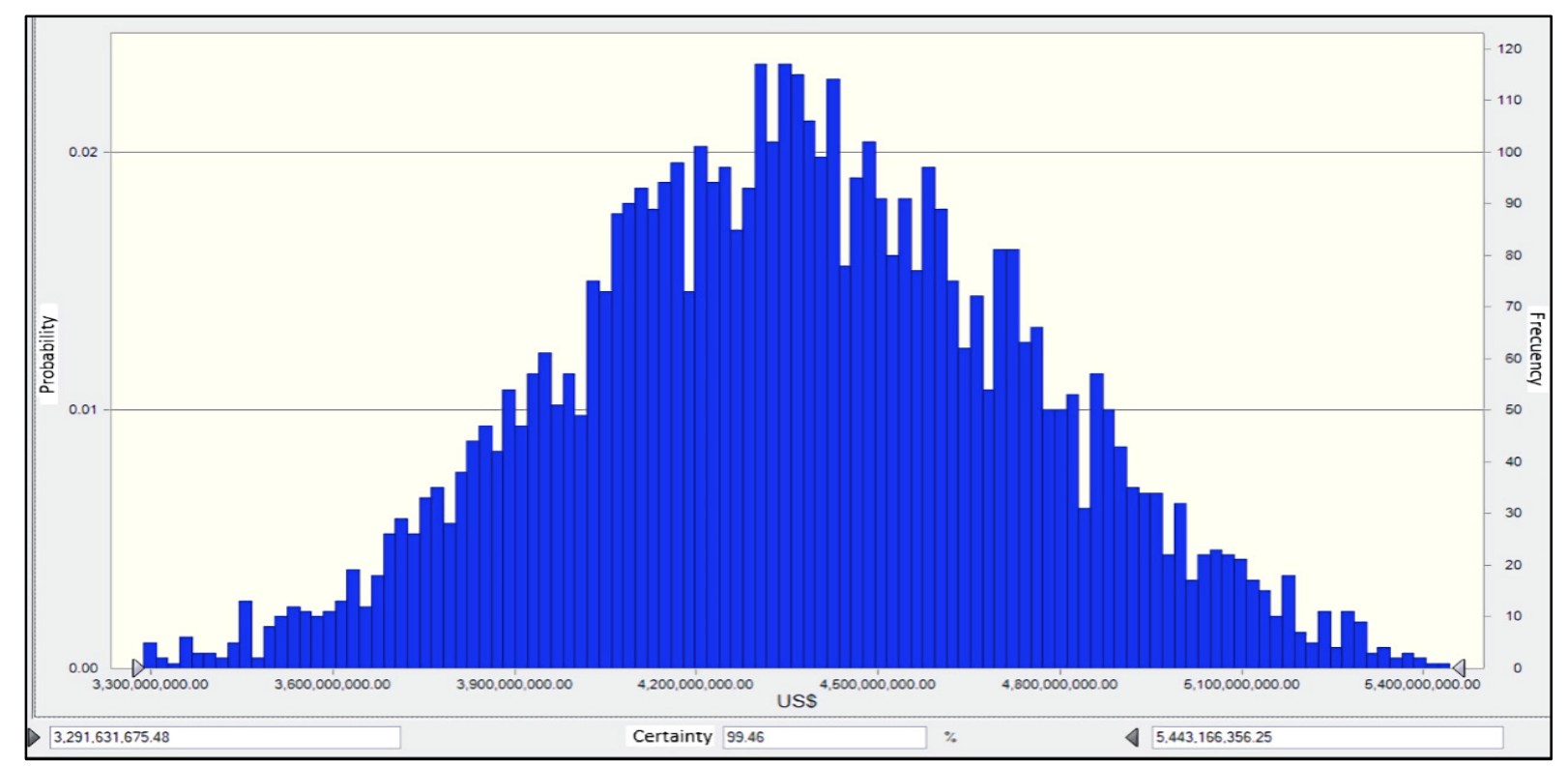

Figure 2. Monte Carlo simulation for project NPV

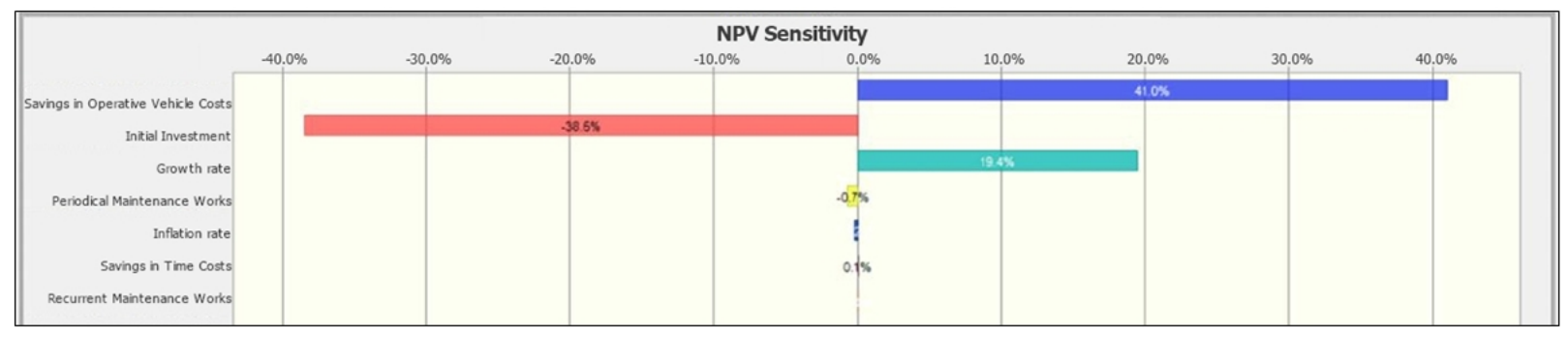

Figure 3. Project sensitivity analysis

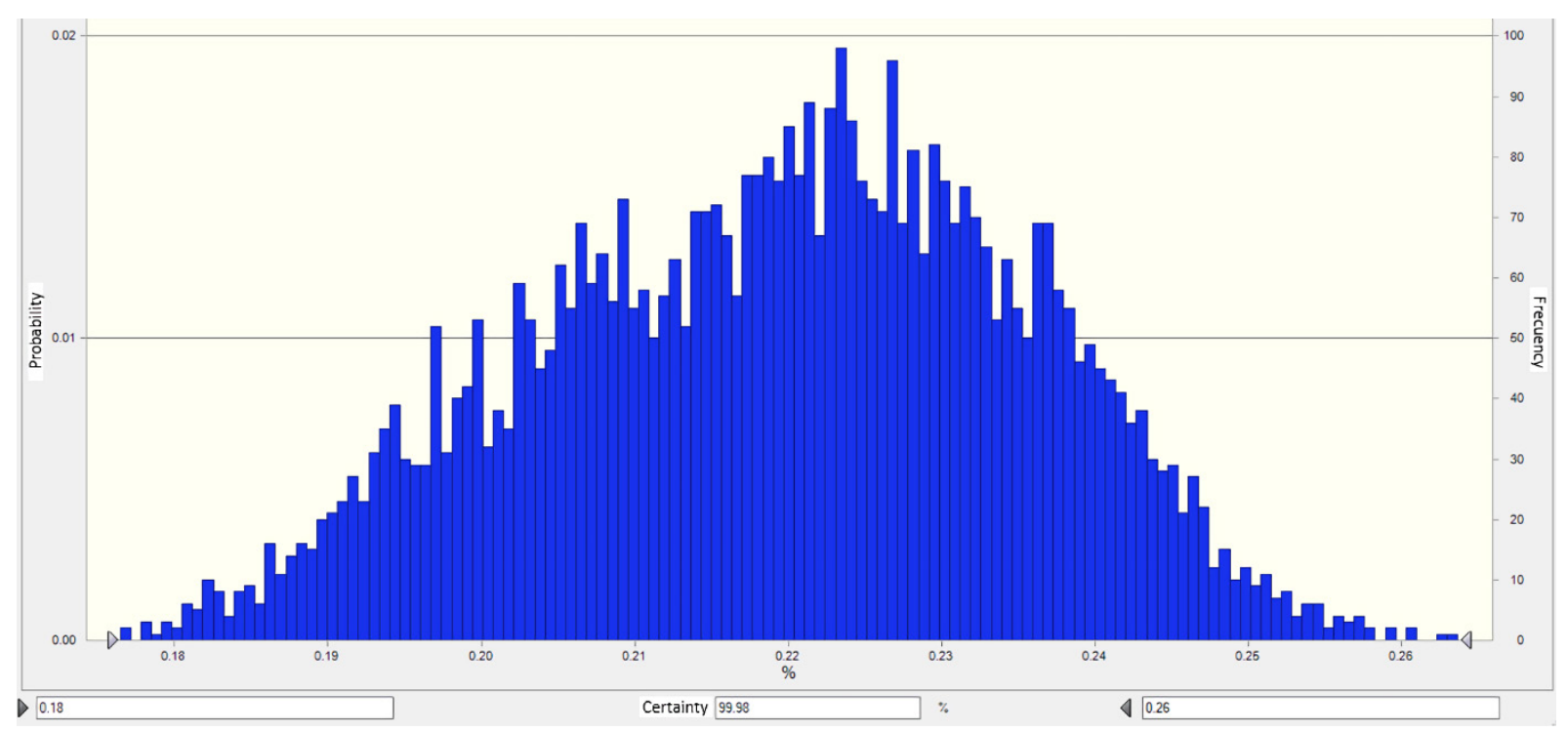

Figure 4. Monte Carlo simulation for project IRR

\section{Discussion}

This study analyzed the Daniel Alcides Carrión risks using the Monte Carlo simulation. Hence, it has been found a big probability of the project being environmentally profitable. Besides, the study found that savings in operative vehicle costs and traffic growth rate were fundamental for highway sustainability. Moreover, the research found that the importance of expense control on investments is due to their negative correlation with 
project feasibility. Compared with the [15] finding, the research found that the project has a probability of $99.46 \%$ to provide benefits. Furthermore, it has been encountered that the importance of the initial budget agrees with the results of [16]. Moreover, it has been discovered that an inverse relationship between maintenance costs and the project's NPV is like the findings of [21].

Additionally, in the investment stage, placement and equipment availability played an important role in the project's NPV like [18]. Besides, the study found that savings in operative vehicle costs had a strong correlation to the project's NPV as [17].

The analysis results did not match with the findings of [18] in maintenance issues. However, it does not mean that maintenance is not important for highway sustainability. Also, although political change has not been measured, it is well known the Peruvian political instability as [21] claimed. Time savings and maintenance costs did not have any significant effect on the sensitivity analysis. Hence, those results do not match with the findings of [22].

\section{Conclusions}

The current research employed the Monte Carlo simulation to evaluate the risk of the Daniel Alcides Carrión highway. Therefore, it was necessary to rebuild its cash flows and select the variables. After applying the Monte Carlo simulation, it has been found a high probability to obtain profitable NPV and high IRR. Moreover, it has been found that the savings in operative vehicle costs and traffic growth rate had positive relationships with the project's NPV. However, investment can hurt it.

Therefore, the studied highway to be sustainable should avoid over expenses and delays in the whole project. Hence, cost efficiency policies become extremely necessary. Moreover, disaster prevention strategies are needed to maintain the flux of the road when incidents occur [28]. Therefore, operations costs growth for vehicles and delays can be diminished as recommended by [29]. With those measures, the new highway can attract more drivers as an alternative to the Carretera Central road, hence, increasing the highway sustainability in the future.

Implications of this research are both economic and social. First, this research employs an approach that can evaluate future scenarios with risks to the budget and economic efficiency appropriately. Thus, after analyzing them, this road will give social benefits to the population. Moreover, this highway will not be a waste of scarce resources providing savings in time and costs. Consequently, this project will give a modern solution to the problem detailed in the introduction part.

\section{Acknowledgments}

We are very grateful to experts for their appropriate and constructive suggestions to improve this template.

\section{REFERENCES}

[1] Ivanová E., Masárová J.. "Importance of Road Infrastructure in the Economic Development and Competitiveness," Economics and Management, vol. 18, no. 2 pp.263-274, 2013. DOI: http://dx.doi.org/10.5755/j01 .em.18.2.4253

[2] Schneider I. "Transportation and quality of life," in Quality of Life: Assessment for Transportation Performance Measures, 1st ed, MN/RC 2013-05, 2013, pp 1-161.

[3] Aldagheiri M. "The role of the transport road network in the economic development of Saudi Arabia," WIT Transactions on the Built Environment, vol. 107, pp. 275285, 2009. DOI: 10.2495/UT090251.

[4] Harral C. "Technical Options and Their Economic Consequences," in Road Deterioration in Developing Countries, 1st ed, A World Bank policy study,1988, pp. $1-76$.

[5] Bonifaz J., Urrunaga R., Aguirre J., Quequezana P. "Cálculo de la Brecha de Acceso Básico a Infraestructura de Largo Plazo" in Brecha de infraestructura en el Perú: Estimación de la brecha de infraestructura de largo plazo 2019-2038, 1st ed, Banco Interamericano de Desarrollo, 2020, pp. 1-121.

[6] INSTITUTO PERUANO DE ECONOMÍA. "BRECHA EN INFRAESTRUCTURA DE TRANSPORTE", INSTITUTO PERUANO DE ECONOMÍA. http://www.ipe.org.pe/portal/wp-content/uploads/2018/02/ 2017-06-Infraestructura-de-transportes-Revista-Costos.pdf (accesed May 12, 2021).

[7] Mendieta N., Suito A. "Problemática de la Carretera Central", Universidad de Piura, https://pirhua.udep.edu.pe/ handle/11042/3586 (accesed May 14, 2021).

[8] Alarcón F. "La importancia de la carretera central", Ministerio de Transprotes y Comunicaciones, https://portal.mtc.gob.pe/transportes/terrestre/documentos/ REPORTE SOBRE VÍA ALTERNA A LA CARRETERA CENTRAL v5 - NEUTRO.pdf (accesed May 18, 2021).

[9] Morín E. Boletín: "La inversión pública, la evalución de proyectos y la gestión de elefantes blancos", Centro de Estudios para la Preparación y Evaluación Económica de Proyectos,

https:/www.cepep.gob.mx/work/models/CEPEP/metodolo gias/boletines/Boletin_7_Inv\%20Publica_ESP_y_Elefante s_Blancos.pdf (accesed May 17, 2021)

[10] Ávila J. "Aplicación de la simulación Monte Carlo para el control de ampliaciones de plazo y adicionales en obras públicas con base en un análisis de las obras ejecutadas en el distrito de San Isidro, periodo 2012-2017", Pontificia Universidad Católica del Perú, http://tesis.pucp.edu.pe/rep ositorio/handle/20.500.12404/15532 (accesed May 21, 
2021).

[11] Sánchez E. "Análisis de riesgos en proyectos de inversión," Pensamiento Crítico, no. 11, pp. 129-138, 2014. DOI: $10.15381 /$ pc.v11i0.9014.

[12] Pérez S., Cruz D., Quiroz L. "Análisis de sensibilidad de indicadores financieros en la evaluación de inversiones en Mipymes", Universidad Autónoma del Estado de Hidalgo, https://www.uaeh.edu.mx/investigacion/productos/5523/ (accesed May 16, 2021).

[13] Dirección General De Programación Multianual De Inversiones Del Ministerio De Economía Y Finanzas. "Guía General para la Identificación, Formulación y Evaluación de Proyectos de Inversión", Ministerio de Economía y Finanzas, https://www.mef.gob.pe/contenidos/ inv_publica/docs/Metodologias_Generales_PI/GUIA_EX ANTE_InviertePe.pdf (accesed May 23, 2021).

[14] Azofeifa C. "Aplicación de la Simulación Monte Carlo en el cálculo del riesgo usando Excel," Tecnología en Marcha, vol. 17 , no. 1, pp. 97-109, 2004. DOI: 10.2307/3279087.

[15] Inquilla J., Rodrígue O. "Análisis de riesgo mediante el método de simulación de Montecarlo aplicado a la inversión pública en el sector educativo peruano: el caso del departamento de Puno," Praxis, vol. 15, no. 2, pp. 163-176, 2019 DOI: 10.21676/23897856.2858.

[16] Arba R., Jecan S., Rusu L., Sitar D.. "A Monte Carlo simulation method for risk management in road pavement maintenance projects," Environmental Engineering and Management Journal, vol. 18, no. 8, pp. 1639-1646, 2019 DOI:10.30638/eemj.2019.154.

[17] Kazaku E., Zvereva E., Tsarionova J.. "The transport construction investment project effectiveness assessment by Monte Carlo Method," IOP Conference Series: Materials Science and Engineering, 2020, vol. 913, no. 5, pp. 0-7. DOI: 10.1088/1757-899X/913/5/052006.

[18] Grossberger H., Mauler C., Michelberger F.. "Lifecycle Based User Value Analysis of Rail - Road Level Crossings: Probabilistic Approach Using Monte Carlo Simulation," Procedia Engineering, vol. 178, no. October pp. 409-418, 2017. DOI:10.1016/j.proeng.2017.01.079.

[19] Joubert F., Pretorius L. "Using Monte Carlo simulation to create a ranked check list of risks in a portfolio of railway construction projects," South African Journal of Industrial Engineering, vol. 28, no. 2, pp. 133-148, 2017. DOI: 10.7166/28-2-1604.
[20] Platon V., Constantinescu A. "Monte Carlo Method in Risk Analysis for Investment Projects," Procedia Economics and Finance, vol. 15, no. 14, pp. 393-400, 2014. DOI 10.1016/s2212-5671(14)00463-8,2014.Availabl $\mathrm{e}$

[21] Sharma K. "Monte Carlo Simulation Applications for construction," International Journal of Civil Engineering and Technology, vol. 11, no. 2, pp. 88-100, 2020. Article ID: IJCIET_11_02_010. Available at SSRN: https://ssrn.com/abstract $=3540232$

[22] Salling K., Leleur S. "Assessment of transport infrastructure projects by the use of monte carlo simulation: The CBA-DK model," Proceedings - Winter Simulation Conference, 2006, pp. 1537-1544. DOI: 10.1109/WSC.2006.322924.

[23] Gonzáles A., GARCÍA G. "Análisis de Sensibilidad" in Manual Práctico de Investigación de Operaciones, 4th ed, ECOE EDICIONES, 2015, pp. 1-300.

[24] Cornejo C. "Desarrollo del proyecto" in Negocio Inmobiliario, 1st ed, Universidad de Ciencias Aplicadas, 2018 pp. 1-176.

[25] Virine L., Trumper M. "What is Project Risk?" in Project Decisions, 2nd ed, Berret-Koheler Publishers, 2019 pp. $1-321$.

[26] Wali K., Othman S. "Schedule Risk Analysis Using Monte Carlo Simulation for Residential Projects. Zanco Journal of Pure and Applied Sciences," vol. 31, no. 5, pp.90-103, 2019. DOI: $10.21271 /$ zjpas.31.5.11.

[27] Ministerio de Economía y Finanzas. "Guía Metodológica para la identificación, formulación y evaluación social de proyectos de vialidad interurbana a nivel de perfil", Dirección de Política y Estrategias de Inversión Pública, https://www.mef.gob.pe/contenidos/inv_publica/docs/nor mas/normasv/2015/RD003-2015/Guia_Interurbana.pdf (accesed May 25, 2021).

[28] Leuhery H. "Determination of black site area based on equivalent accident number analysis: Case study national roads in ambon city", Civil Engineering and Architecture, vol 8, no. 5, pp. 1063-1073, 2020. DOI: 10.13189/cea.2020.080533

[29] Harish L., Nagakumar M., Swathi, H. "Impact assessment and prioritization of critical delay factors for a road project", Civil Engineering and Architecture, vol. 8, no. 6, pp. 1325-1334, 2020. DOI: 10.13189/cea.2020.080616 